\title{
Entomofaunal diversity of Diptera in a semi arid region in the west of Algeria (Tiaret)
}

\author{
Samra Mohdeb*', Samia Ouarab², Faiza Marniche ${ }^{3}$ \& Fatiha Labedelli' \\ ${ }^{1}$ Faculty Sciences of Nature and Life, Laboratory of Agrobiotechnology and Nutrition in Semi-arid Zone, Ibn-Khal- \\ doun University of Tiaret, 14000, Algeria \\ ${ }^{2}$ Department of Biotechnology, Faculty science of nature and life, Animal Ecobiologie laboratory, University of \\ Saad Dahlab Blida 1, 09000, Blida, Algeria \\ ${ }^{3}$ Laboratory of zoology, National School of Veterinary, 16000, Algiers, Algeria, \\ *Corresponding author, email: samramohdeb.13@gmail.com
}

\begin{abstract}
The contribution to the study of the biodiversity of Diptera associated with the cultivated olive tree took place over a year from December 2018 to November 2019, in two stations located in the west of Algeria. The aim of this present work is to learn about the biodiversity of Diptera associated with the olive tree cultivated in the Tiaret region. Sampling frequency was on the order of one outing per month using the yellow plates and barber jars to collect the specimens. We identified 1124 individuals or 46 species belonging to 29 families. The Sciaridae family is the most representative in Ain Guesma station with a relative abundance AR\% of $23 \%$. While in the station of Oued lili the Chirinominidae family is the most captured, at $18.52 \%$. The two stations present a great diversity of species ( $\mathrm{H}^{\prime}=3.58$ Ain Guesma, $\mathrm{H}^{\prime}=3.65$ in Oued Lili). The equity of the species identified in this study is greater than or equal to 0.76 .
\end{abstract}

KEY WORDS Algeria; Biodiversity, Chironomidae; Diptera; Sciaridae; Chironominidae.

Received 13.1.2021; accepted 30.05.2021; published online 24.07.2021

\section{INTRODUCTION}

Diptera have an important and recognized ecological role. They participate in the pollination of small flowers, not appreciated by large insects. They protect small plants, which didn't find a taker and they therefore have an essential role for the ecosystem. They are also at the top of the food chain for terrestrial insects and as insect predators. Their characteristics sensitive to changes in habitat and environment can be used as a valuable biological indicator of environmental change or habitat disturbance (Samways, 1995).

The Diptera Linnaeus, 1758 is the largest order in the biosphere (Ashley et al., 2017). In the world there are 160,000 species (Pape et al., 2011) and approximately there are 160 families (Savage et al., 2019). This order is called real flies or wing flies. It is a group of insects that contains flies, mosquitoes, horse fly, black flies, fruit flies, and house flies (Courtney et al., 2017). The order of the Diptera had been the subject of several studies both in the world and in Algeria. Among these, it is to quote those of Siti Khairiyah et al. (2013) in Malysie, of Brown et al. (2018) in Costa Rica, and of Savage et al. (2019) in Canada. In Algeria, work on Diptera is undertaken by Dedet et al. (1984) in Constantine, Zerguine et al (2018) in the east of Algeria, Djelleb et al. (2013) in the North-West of Algeria, Bounouira (2016) and Belkharchouche et al. (2020) in Tiaret, and Baba Aissa et al. (2017) in the Sahara (Mestfaoui et al., 2020).

This study aims to determine the different species of Diptera in two cultivated orchards located in the west of Algeria, Tiaret and to compare their diversity and abundance in different regions. 


\section{MATERIAL AND METHODS}

\section{Study area}

This present work was carried out in two stations located in the west of Algeria, Tiaret. The first orchard is located in Oued Lili $\left(35^{\circ} 22^{\prime} 15^{\prime \prime} \mathrm{N}\right.$ $1^{\circ} 19^{\prime} 01^{\prime \prime} \mathrm{E}$; Fig. 1) which is located to the northeast of Tiaret. It has an area of 3 ha of cultivated Olea europaea, Sigoise variety. It is a very well maintained orchard.

The second orchard is located in Ain Guesma $\left(35^{\circ} 15^{\prime} 1^{\prime \prime} \mathrm{N}-1^{\circ} 19^{\prime} 55^{\prime \prime} \mathrm{E}\right.$; Fig. 1) south of the center of Tiaret. This plot is occupied by 5 ha of Olea europaea cultivated variety of Sigoise. It is almost abandoned and unmaintained orchard.

\section{Sampling method}

In order to count the Diptera, two methods were chosen, the method of Baber pots and the method of yellow plates. The principle of both methods is to fill $1 / 3$ of each container (Barber jar and yellow plate) with water, adding a detergent to prevent trapped invertebrates from escaping. This 10 traps are placed in line for the Barber pots and for the yellow plates, separated by intervals of 5 meters. These samplings are carried out over a year from December 2018 to November 2019 at the rate of a monthly release, on the 15 th of each month.

The traps remain in site the field for 24 hours. The trapped species are collected in eppendorfs filled with $70 \%$ alcohol, mentioning the trap number

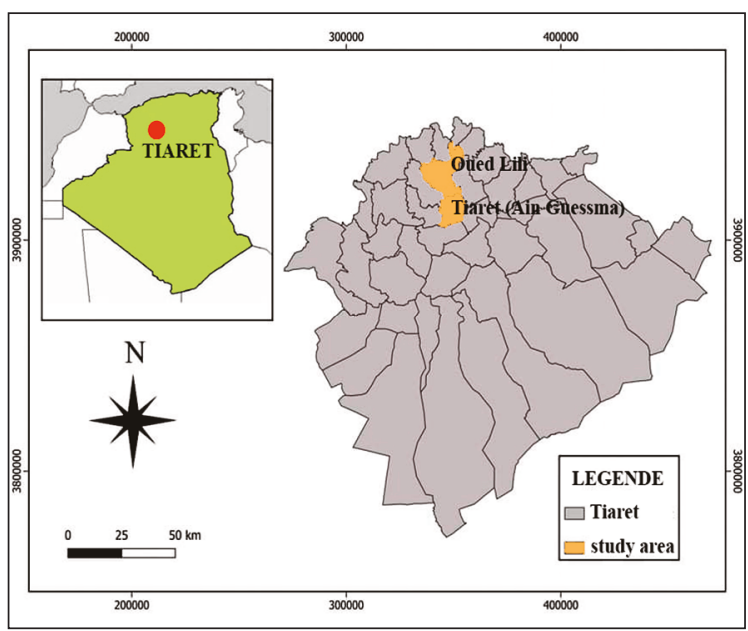

Figure 1. Geographical location and administrative division of Tiaret region in Algeria. Situation of the two sampling localities. and the date of trapping. Only the contents of 8 traps are taken into account.

The identification of the species was done at the zoological laboratory at the national school of veterinarian with Professor Marniche Faiza using available keys and original descriptions (Séguy, 1923, 1934; Hutson et al., 1980; Bechev \& Koç, 2006; Babytskiy et al., 2019; Seunggwan et al., 2019).

\section{Exploitation of results}

The results obtained are used by the following diversity indices:

- The total richness (S) which is the total number of species found in each station (Blondel, 1975);

- The relative abundance (AR\%) which is the percentage of individuals of a species $i$ taken into consideration in relation to the total of individuals, all species combined (Dajoz, 1971; Bigot \& Bodot, 1973);

- The Shannon-Weaver diversity index (H'), considered to be one of the best means of expressing the diversity of an assemblage (Blondel et al., 1973), it makes it possible to obtain information on the diversity different environments (Abarken, 2014) and which is obtained by the formula: $H^{\prime}=-q i \log 2$ qi where $H^{\prime}$ is the diversity index expressed in bits and qi the relative frequency of the species i considered. According to Prakash and Amita, 2012, if the range of $\mathrm{H}^{\prime}$ is 1 to 2.4 , it indicates that the site has low diversity, if the range is 2.5 to 3.5 , it has diversity of moderate species, and if the range is 4.0 above indicate a high species diversity.

- The equity index (E) which is the ratio of observed diversity $\left(H^{\prime}\right)$ to maximum diversity ( $H$ ' max) (Barbault, 1981; Ramade, 1984; Dajoz, 2000). The maximum diversity is given by the formula: $\mathrm{H}$ ${ }^{\prime} \max =\log 2 \mathrm{~S}$ where $\mathrm{S}$ is the total richness (Ramade, 1984). Equity varies between 0 and 1 .

\section{RESULTS AND DISCUSSION}

The contribution to knowledge of the biodiversity of Diptera in the Tiaret region has enabled us to identify 1124 individuals, or 46 species belonging to 29 families. In the present work we collected 26 families in the Ain Guesma station and 23 families in the Oued Lili station (Table 1). 


\begin{tabular}{|c|c|c|c|c|}
\hline \multirow[t]{2}{*}{ Families } & \multicolumn{2}{|c|}{$\begin{array}{c}\text { Station Ain } \\
\text { Guesma }\end{array}$} & \multicolumn{2}{|c|}{ Station Oued Lili } \\
\hline & $\mathrm{Ni}$ & AR(\%) & $\mathrm{Ni}$ & $\operatorname{AR}(\%)$ \\
\hline Agromyzidae & 3 & 0.40 & 3 & 0.79 \\
\hline Anthomyiidae & 14 & 1.87 & 10 & 2.65 \\
\hline Biblionidae & 0 & - & 1 & 0.26 \\
\hline Calliphoridae & 14 & 1.87 & 5 & 1.32 \\
\hline Cecidomyiidae & 73 & 9.78 & 38 & 10.05 \\
\hline Chironomidae & 25 & 3.35 & 70 & 18.52 \\
\hline Ceratopogonidae & 10 & 1.34 & 7 & 1.85 \\
\hline Dolichopodidae & 13 & 1.74 & 6 & 1.59 \\
\hline Drosophilidae & 54 & 7.23 & 22 & 5.82 \\
\hline Ephydridae & 6 & 0,80 & 6 & 1.59 \\
\hline Faniidae & 1 & 0.13 & 0 & 0 \\
\hline Heleomyzidae & 3 & 0.40 & 0 & 0 \\
\hline Hybotidae & 75 & 10.05 & 13 & 3.44 \\
\hline Mycetophilidae & 39 & 5.22 & 26 & 6.88 \\
\hline Muscidae & 0 & 0 & 1 & 0.26 \\
\hline Opomyzidae & 2 & 0.26 & 3 & 0.79 \\
\hline Phoridae & 33 & 4.42 & 49 & 12.96 \\
\hline Piophilidae & 97 & 13.00 & 11 & 2.91 \\
\hline Pipunculidae & 1 & 0.13 & 0 & 0 \\
\hline Psychodidae & 2 & 0.26 & 14 & 3.70 \\
\hline Psilidae & 1 & 0.13 & 0 & 0 \\
\hline Scatopsidae & 25 & 3.35 & 32 & 8.47 \\
\hline Sciaridae & 168 & 22.52 & 56 & 14.81 \\
\hline Simuliidae & 0 & 0 & 1 & 0.26 \\
\hline Sphaeroceridae & 3 & 0.40 & 1 & 0.26 \\
\hline Syrphidae & 2 & 0.26 & 2 & 0.53 \\
\hline Tabanidae & 1 & 0.13 & 0 & 0 \\
\hline Tephritidae & 80 & 10.72 & 0 & 0 \\
\hline Trichoceridae & 1 & 0.13 & 1 & 0.26 \\
\hline Total & 746 & 100 & 378 & 100 \\
\hline
\end{tabular}

The Sciaridae Billberg, 1820 is the most captured family at the Ain Guesma station (AR\% = 22.52\%). It is represented by the genera Bradysia Winnertz, 1867 and Lycoriella Frey, 1942. Sciaridae are known as black midges because of their dark color (Carvalho-Fernandes, 2016). The larvae of this family live in the soil, under the bark of trees, on the mycelium or in the bodies of fungi (Frank et al., 2003). They play a role in the decomposition of organic matter. Nevertheless, Sciaridae species are considered harmful to crops (Babytskiy et al., 2019). This family is less representative in Oued Lili, i.e. $14.81 \%$.

The most representative family in the Oued Lili station is Chironominidae with a relative abundance of $18.52 \%$ ( $\mathrm{ni}=70$ individuals) (Table 1$)$. The presence of running water near this station justifies its high dominance. Unlike the Ain Guesma station where it is less representative ( $\mathrm{AR}=3.35 \%$ ).

The genus collected from the two stations is Chironomus Meigen, 1800. Chironominidae are a very diverse group of aquatic insects, found in high density in different types of ecosystems. They are of great importance in the structure and function of lotic systems due to their great abundance, diversity and occurrence (Cranston, 1995). Chironomus larvae are found in polluted areas or flowing waters (Carlos et al., 2019).

Chironomids have attracted the attention of many scientists, interested in studying giant chromosomes in larval salivary glands, hemoglobin, morphological aberrations, usually related to specific stressors (e.g. thermal and chemical) (Armitage et al., 1995).

In Ain Guesma the Piophilidae Macquart, 1835 family comes second after the Sciaridae family with a rate of $13 \%(\mathrm{ni}=97)$ (Table 1$)$ and weakly represented in Oued Lili. It includes the species Piophila casei (Linnaeus, 1758) which is important in forensic entomology because it is informative for the estimation of the postmortem interval (Smith, 1986). In Italy, $P$. casei larvae are often introduced into pecorino cheese to promote fermentation. They create a unique flavor in cheese (Nanzi et al., 2008).

The Tephritidae Newman, 1834 family is classified in third position in Ain Guesma, i.e. 10.72\% $(\mathrm{ni}=80)$. It is represented by two genera, the first is Bactrocera Macquart, 1835 and the second is Ceratitis Macleay, 1829. Tephritidae are known by the name of fruit fly (Marcoandre et al., 2016). Females of this family are characterized by a long

Table 1. The relative abundance of Diptera families in two stations. AR\%: Relative abundance. Ni: Number of individuals. 
and expandable ovipositor that is used to lay eggs under the skin of fruits and vegetables where the larvae develop and feed (Delrio \& Cocco, 2012). Most species of this family cause qualitative and quantitative damage to plants of economic interest (Foote, 1967). This family is not present in Oued Lili because the orchard is maintained unlike the orchard of Ain Guesma.

The family Cecidomyidae is registered in the two stations with an approximate relative abundance of $10 \%$ each. It is represented by three subfamilies including Micromyiinae, Lestremiinae and Cecidomyiinae. According to Maia (2016), Micromyiinae and Lestremiinae are fungivores. Flies and other Diptera are plant pests; they cause direct damage and also economic losses (Gagné, 1994).

The family of Phoridae Latreille, 1796 is counted with a relative abundance of $12.96 \%$ in Oued Lili and $4.42 \%$ in Ain Guesma. In this family we have counted three genera including Megasellia Rondani, 1856, Conicera Meigen, 1830 and Phora Latreille, 1796. The Phoridae, also called scuttle flies, are one of the most biologically diverse families on Earth. In this family, the most representative genus is Megasellia. They are found in almost all terrestrial habitats except cold and dry places (Disney, 1994). This family includes decomposers, fungivores, phytophages, inquilines, predators and parasitoids (Savage et al., 2019).

The Hybotidae family is counted with a rate of $10.05 \%$ in Ain Guesma and 3.44\% in Oued Lili. The representative genus of this family is Platypalpus. Species in this family are predators and others feed on nectar and pollen (Chvála, 1976).

From Table 2, we notice that the highest diversity index is recorded in Oued Lili with 3.65 Bits. For Ain Guesma station the diversity is 3.58 bits. According to Prakash \& Amita (2012), if the range of $\mathrm{H}^{\prime}$ is 4.0 above indicates a great diversity of species. The equity index of the species identified in this study is greater than or equal to 0.76 . These values all tend towards 1 . As a result, the two stations are diversified throughout our sampling $(0.76$ $\leq \mathrm{E}<0.81)$.

\section{CONCLUSIONS}

The contribution of the study of the entomofauna of Diptera associated with the olive tree cultivated

\begin{tabular}{|l|c|c|c|}
\hline Stations of study & H' & Hmax & E \\
\hline Ain Guesma & 3.58 & 4.70 & 0.76 \\
\hline Oued Lili & 3.65 & 4.52 & 0.81 \\
\hline
\end{tabular}

Table 2. Shannon-Weaver diversity index and equity index to the two stations. H': Shannon-Weaver diversity index. Hmax: Maximum diversity. E: equity index.

in a semi- arid region Tiaret (Algeria), took place for a year between December 2018 and November 2019 in two stations: Oued Lili and Ain Guesma. 1124 individuals were collected or 46 species belonging to 29 families. The Sciaridae family is the most representative in Ain Guesma station with a relative abundance $\mathrm{AR} \%$ of $23 \%$. While in the station of Oued lili the Chirinominidae family is the most captured, at $18.52 \%$. The two stations present a great diversity of species $\left(\mathrm{H}\right.$ '=3.58 Ain Guesma, $\mathrm{H}^{\prime}=3.65$ in Oued Lili). The equity of the species identified in this study is greater than or equal to 0.76 .

\section{REFERENCES}

Aberkane F., 2014. Diversité altitudinale des Carabidae (Insecta, Coleoptera) dans la région de Tikjda. Mémoire de magister, Ecole national supérieure d'agronomie, Algérie.

Armitage P.D., Cranston P.S. \& Pinder L.C.V., 1995. The Chironomidae: the biology and ecology of non-biting midges. Chapman \& Hall, London.

Ashley H., Kirk S. \& Bradley J.S., 2017. Manual of afrotropical diptera. Pretoria, South Africa.

Baba Aissa N., Doumandji S.D. \& Ebejer M.J., 2017. First records of Aphaniosoma Becker ( Diptera: Chyronomyidae) from Algeria. African Entomology, 25: 481-484. https://doi.org/10.4001/003.025.0481

Babytskiy A.O., Moroz M.S., Kalashnyk S.O., Bezsmertna O.O., Dudiak I.D. \& Voitsekhivska O.V., 2019. New findings of pest sciarid species (Diptera, Sciaridae) in Ukraine, with the first record of Bradysia difformis. Biosystems Diversity, 27: 131-141.

Balenghien T., 2020. Update of the Culicoides (Diptera: Ceratopogonidae) species checklist from Algeria with 10 new records. Parasites Vectors, 13: 463.

Barbault R., 1981. Écologie des populations et des peuplements des théories aux faits. Éd. Masson, Paris, $200 \mathrm{pp}$.

Bechev D.N. \& Koç H., 2006. Two new species of Sciophila Meigen (Diptera: Mycetophilidae) from Turkey, 
with a key to the Western Palaearctic species of the S. lutea Macquart group. Zootaxa, 1253: 61-68. https://doi.org/10.5281/zenodo.173048

Belkharchouche M., Berchi S., Mathieu B., Rakotoarivony I., Duhayon M., Baldet T., Zerguine K., Samraoui B. \& Rossaro B., 2009. A survery of chironomids from seasonal pounds of Numidie, Northeas tern Algeria. bioll. Bollettino di Zoologia agraria e di Bachicoltura, Ser. II, 41: 167-174.

Bigot L. \& Bodot P., 1973. Contribution à l'étude biooenotique de la garrigue à Quercus coccifera. Vie et Milieu, 23, sér. C : 229-249.

Blondel J., Ferry C. \& Frochot B., 1973. Avifaune et végétation, essai d'analyse de la diversité. Alauda, $10: 63-84$.

Blondel J., 1975. L'analyse des peuplements d'oiseaux, éléments d'un diagnostic écologique. I. La méthode des échantillonnages fréquentiels progressifs (E.F.P.). Revue d'Ecologie (La Terre et la Vie), 29: 533-589.

Bounouira Y., 2016. Ecologie des Diptères vecteurs lies aux bovins dans la region montagneuse des Ouarsenis (Nord-Ouest Algérien). Mémoire de magister. Université Abou-Baker Belkaid Tlemcen.

Brown B.V., Borkent A., Adler P.H., de Souza Amorim D., Barber K., Bickel D., Boucher S., Brooks S.E., Burger J., Burington Z.L., Capellari R.S., Costa D.N.R., Cumming J.M., Curler G., Dick C.W., Epler J.H., Fisher E., Gaimari S.D., Gelhaus J., Grimaldi D.A., Hash J., Hauser M., Hippa H., Ibáñez-Bernal S., Jaschhof M., Kameneva E.P., Kerr P.H., Korneyev V., Korytkowski C.A, Kung G.-A., Kvifte G.M., Lonsdale O., Marshall S.A., Mathis W., Michelsen V., Naglis S., Norrbom A.L., Paiero S., Pape T., Pereira-Colavite A., Pollet M., Rochefort S., Rung A., Runyon J.B., Savage J., Silva V.C., Sinclair B.J., Skevington J.H., Stireman Iii J.O., Swann J., Thompson F.C., Vilkamaa P., Wheeler T., Wong M., Wood D.M., Woodley N., Yau T., Zavortink T.J. \& Zumbado M.A., 2018. Comprehensive inventory of true flies (Diptera) at a tropical site. Communications biology, 1: 21. https://doi.org/10.1038/s42003-018-0022-x

de Vasconcelos Nascimento C.H., Pereira-Silva R., Arruda dos Santos I.G., 2019. Chironomidae (Insecta: Diptera) from four protected areas in the state of Pernambuco, Brazil. Aquatic Insects, 40: 1-27. https://doi.org/10.1080/01650424.2018.1557690

Carvalho-Fernandes S.P., 2016. Family Sciaridae. Zootaxa 4122 (1): 41-45. https://doi.org/10.11646/zootaxa.4122.1.7

Chvála M., 1976. Swarming, mating and feeding habits in Empididae (Diptera), and their significance in evolution of the family. Acta Entomologica Bohemoslovaca, 73: 353-366.

Courtney G.W., Pape T., Skevington J.H. \& Sinclair B. J., 2017. Insect Biodiversity: Science and Society.
Biodiversity of Diptera, chapter 9 .

https://doi.org/10.1002/9781118945568.ch9

Cranston P.S., 1995. Biogeography. In: Armitage, P.D., Cranston, P.S., Pinder, L.C.V., eds., The Chironomidae: biology and ecology of non-biting midges. Chapman and Hall, London: 62-84.

Dajoz R., 1971. Précis d'écologie. Éd. Dunod, Paris, 434 pp.

Dajoz R., 2000. Préçis d'écologie. Éd. Dunod, Paris, $615 \mathrm{pp}$.

Dedet J.P., Addadi K. \& Belazzoug, S., 1984. Les phlébotomes (Diptera, Psychodidae). Cahier de l'ORSTOM: Série entomologie médicale et parasitologie, 21: 99-127.

Delrio G. \& Cocco A., 2012. Tephritidae, pp. 206-222. In: Vacante V. \& Gerson U. (Ed.), Integrated Control of Citrus Pests in the Mediterranean Region. https://doi.org/10.2174/97816080529431120101

Disney R.H.L., 1994. Scuttle Flies: the Phoridae. Chapman and Hall, London.

Djellab S., Van Eck A. \& Samraoui B., 2013. A survey of the hoverflies of northeastern Algeria (Diptera: Syrphidae). Egyptian Journal of Biology, 15: $1-12$.

Foote R.H., 1967. Family Tephritidae (Trypetidae, Trupaneidae). In: Papavero N. (Ed.), A catalogue of the Diptera of the Americas south of the United States. Departamento de Zoologia, Secretaria da Agricultura, São Paulo.

Gagné R.J., 1994. The Gall Midges of the Neotropical Region. Cornell University Press, Ithaca, New York, $352 \mathrm{pp}$.

Hutson A.M., Ackland D.M. \& Kidd L.N., 1980. Mycetophilidae (Bolitophilinae, Ditomyiinae, Diadocidiinae, Keroplatinae, Sciophilinae and Manotinae) Diptera, Nematocera. Royal Entomological Society of London, Handbooks for the Identification of British Insects Vol. IX, Part 3, 111 pp.

Maia C.V., 2016. Family of Cecidomyiidae. Zootaxa, 4122 : 26-40.

https://doi.org/10.11646/zootaxa.4122.1.6.

Marcoandre S., Luciane M. \& Allen L.N., 2016. Family of Tephritidae. Zootaxa, 4122: 596-621.

https://doi.org/10.11646/zootaxa.4122.1.50

Mostefaoui O., Sekour M., Balmès V. \& Ben Halima K.M., 2020. Emergence de Ceratitis capitata (Diptera: Tephritidae) sur culture protégée de piment (Solanaceae) en zone subsaharienne (Algérie). Bulletin OEPP/EPPO Bulletin, 0: 1-4.

Nanzi W.A., Jeffery J.I., Noorjuliana W.M., Chen C.D., Rohayu S.A., Hafizam A.H. \& Lee H.L., 2008. First report of maggots of family Piophilidae recovered from human cadavers in Malaysia. Tropical Biomedicine, 25: 173-175.

Pape T., Blagoderov V. \& Mostovski M.B., 2011. Order 
Diptera Linnaeus, 1758, pp. 222-229. In: Z.-Q. Zhang (Ed.), Animal biodiversity: an outline of higher-level classification and survey of taxonomic richness. Zootaxa, 3148: 1-237.

https://doi.org/10.11646/zootaxa.3148.1.42

Ramade F., 1984. Éléments d'écologie - Écologie fondamentale. Édité par McGraw-Hill, Paris, 396 pp.

Samways M.J., 1994. Insect Conservation Biology. 2nd edition. Chapman \& Hall, 1-34 pp.

Savage J., Borkent A., Brodo F., Cumming J.M., Curler G., Currie D.C., deWaard J.R., Gibson J.F., Hauser M., Laplante L., Lonsdale O., Marshall S.A., O'Hara J.E., Sinclair B.J. \& Skevington J.H., 2019. Diptera of Canada. ZooKeys, 819: 397-450. https://doi.org/10.3897/zookeys.819.27625

Séguy E., 1923. Faune de France 6. Diptères Anthomyides.
- Fédération Française des Sociétés de Sciences Naturelles, Paris, 393 pp.

Séguy E., 1934. Faune de France. Diptères (Brachycères) (Muscidae Acalypterae et Scatophagidae). Les presses universitaires de France, Paris, volume 28.

Seunggwan S., Heungsik L. \& Seunghwan L., 2019. Proposal of a new subfamily of Sciaridae (Diptera: Sciaridae), with description of one new species from South Korea. Zootaxa, 4543: 127-136.

Siti Khairiyah M.H., Elfira S.E., Hanysyam N.M., Nurdiana S., Norashirene M.J. \& Faezah P., 2013. Entomofaunal Diversity of Diptera at FELDA Besout 6 Oil Palm Plantation. IERI Procedia, 5: 45-50. https://doi.org/10.1016/J.IERI.2013.11.068

Smith K.G.V., 1986. A manual of forensic entomology. Ithaca, N.Y: Cornell Univ. Press. Chicago, 102 pp. 